\title{
Successive Cultivation of M. lepraemurium by Bacterial Mass Inoculation
}

\author{
TATSUO MORI \\ Department of Leprology, Research Institute for Microbial Diseases, \\ Osaka University, Yamada Kami Suita Osaka Japan
}

Since M. lepraemurium Hawii was isolated on $1 \%$ Ogawa yolk medium, ${ }^{1{ }^{-9}}{ }^{1}$ Kozeki et $\mathrm{al}^{10{ }^{11)}}$ and $\mathrm{Mor}^{{ }^{12)}}$ succeeded in the follow-up-experiments of Ogawa's method, but successive inoculation with smooth suspension was not succeeded, just as described at first by Ogawa.

It was still obscurre that some growth-negative tubes were always observed in cases of successive inoculation and primary isolation, in despite of bacterial mass inoculation. The difficult problem is to solved when the single cell culture of $M$. lepraemurium would be succeeded. As it was very difficult to get $100 \%$ success of the successive inoculation even in the bacterial mass inoculation, some conditions for getting the better efficiency were carefully studied by the method of bacterial mass inoculation.

1) Successive inocualation of $M$. lepraemurium was not affected on the $1 \%$ Ogawa yolk medium without malachite green.

2) Successive inoculation of $M$. lepraemurium was independent on any modified $1 \%$ Ogawa yolk media supplemented respectively with the following substrates: cystin, cystein special agar noble, sodium citrate, sodium $\alpha$-ketoglutarate, glucose, protoporphyrin and water- or butanol-extract of $1 \%$ Ogawa yolk medium on which $M$. lepraemurium had grown.

3) Successive inoculation of $M$. lepraemurium was slightly inhibited on the modified $1 \%$ Ogawa yolk medium supplemented with sodium pyruvate.

4) Addition of hemin to $1 \%$ Ogawa yolk medium gave a good result for successive inoculation of $M$. lepraemurium.

5) In successive inoculation of $M$. lepraemurium, air-loose condition through a small hole in gum stopper gave the better result than air-tight condition without a small hole in it.

6) The organism from old culture over 2 months was not good for successive inoculation, and young rough organism from 30 to 40 days culture was most suitable More over, the organisms should not be scattered on the surface of medium. It was important to inoculate crowdly for getting good results. 


\title{
菌塊接種による鼠瀨菌の継代培養
}

\author{
森竜男 \\ (大阪大学微生物病研究所癩部門)
}

（受付 50 年 1 月27日）

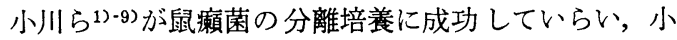
関10)11)，森12)らの追試の成績が報告されているが，小川 らが初期に記載したように菌液にして継代を行うとうま く成功せず，また初代分離培養にて大量菌接種にもかか わらず，常に増殖陰性の試験管が見られることは依然と して解決されていない。

鼠癩菌の単個菌培養ができないようでは自然界に存在 する微量の鼠瀬菌を発見することは不可能であるし，ま た薬剤の効果の判定や増殖促進因子の追跡において, 種 々の困難をともなうことは明らかである。大量菌塊接種 による鼠癩菌の継代培養においても $100 \%$ 継代に成功さ せることは非常にむつかしいので，単個菌培養はしばら くおき，大量菌塊接種による継代培養の条件を種々検討 したので，今回はそれについて報告する。

\section{材料および方法}

継代鼠癩菌は小川らの分離した鼠癩菌様抗酸菌を森 ${ }^{12)}$ のところで Mycobacterium lepraemurium Hawaii と 同定し，約 3 年にわたって継代された菌を用いた。培地 としては $1 \%$ 小川卵黄培地を対照として，修飾 $1 \%$ 小川 卵黄培地は基礎培地に添加物を加えたものを用い， $1 \%$ 小川卵黄培地にならって作った。ヘミン，シスチン，プ ロトポルフィリン，クエン酸は基礎培地に加えてオート クレーブ滅菌し，システイン， $\alpha$-ケトグルタール酸, 焦 性ブドウ酸, ブドウ糖はオートクレーブ隇菌した基礎培 地に後で加えた。ヘミンの添加は中村13)14)の行った方法 に従った。ブタノール抽出培地画分および水抽出培地画 分は $85^{\circ} \mathrm{C}$ の 2 回の間渴滅菌の後, オートクレーブ滅菌 した基礎培地に加えた。基礎培地 $100 \mathrm{ml}$ につき 40 本の卵 黄培地からの抽出物を濃縮して加えた。水抽出の方法は 増殖した鼠瀬菌を除いた後の卵黄培地に蒸溜水 $20 \mathrm{ml}$ を 加え一夜放置し，水層に移る画分を減圧濃縮した。ブタ ノール抽出画分は上記の水抽出を終えた卵黄培地をビー カーに移して水飽和ブタノールを加えて抽出し, 濾紙に
て濾過したブタノール画分を蒸溜水を少量加えながら減 圧濃縮してブタノールを十分に除いた。

マラカイトグリーン（一）というのはマラカイトグリ

ーンを加えずに卵黄培地を作ったものをいう。

ゴム栓 : air tight のゴム栓としてはダブルキャップ ゴム栓を用い, air loase のゴム栓としてはダブルキャ ップゴム栓に手術用絹糸 5 号を 4 重にして通して通気穴 を作ったもの，および栄研のゴムキャップ（内側に側溝 あり)を用いた。

\section{結果}

中村の NC 5 培地 ${ }^{15)}$ にシステインを用いているので, システイン $67 \mu \mathrm{g} / \mathrm{ml}$ になるように加えた修飾 $1 \%$ 小川卵 黄培地を作ってみたが, Table 1にみられるように対照 の $1 \%$ 小川卵黄培地と, 鼠癩菌継代の陽性率において差 はなかった。

小関 ${ }^{16)}$ は $1 \%$ 小川卵黄培地のゴム栓に手術用の糸を通 して通気性としたものを用うると鼠癩菌の発育のいいこ とを報告しているので, air tight と air loose の条件 で $1 \%$ 小川卵黄培地にて鼠癩菌継代陽性率を比較してみ たが, Table 1 にみられるように第 1 回目の成績では 大差なかったが，第 2 回目の成績では air loose の条件 が菌塊の増量の点で air tight の条件よりはるかにまさ っていた。

Table 1 および Table 2 にみられるように，マラカ イトグリーンは加えても加えなくても鼠癩菌の増殖に影 響がなかった。1％小川卵黄培地にシステインを加えた 実験を Table 1 に示したので，シスチンを加えた例を， また寒天にて固めた固型培地を鼠癩菌の増殖促進因子検 索のために用うる関係上, special agar noble を加えた 例を, Table 2 に示したがともに添加物の影響はなく鼠 癩菌はよく増殖した。

中村 ${ }^{15)}$ の No. 5 培地にクエン酸, $\alpha-$ ケトグルタール 酸, 焦性ブドウ酸, ブドウ楉を用いているので, これ 
Table 1 Passage Cultivation of M. lepraemurium on Modified $1 \%$ Ogawa Yolk Media

\begin{tabular}{|c|c|c|c|c|c|c|}
\hline $\begin{array}{c}\text { Date of } \\
\text { Inoculation }\end{array}$ & \multirow{3}{*}{$\begin{array}{c}\begin{array}{c}\text { Days of } \\
\text { Cultivation }\end{array} \\
42 \\
73\end{array}$} & \multirow{3}{*}{$\begin{array}{c}\text { Stopper } \\
\text { Air Tight }\end{array}$} & \multirow[t]{3}{*}{ Modification } & \multicolumn{3}{|c|}{ Results of Tube Numbers } \\
\hline \multirow[t]{4}{*}{$15, \quad 3,1973$} & & & & $+t+28$ & +16 & -59 \\
\hline & & & & $+\quad 48$ & & -55 \\
\hline & 42 & Air Tight & Cystein $67 \mu \mathrm{g} / \mathrm{ml}$ & +++27 & +16 & -61 \\
\hline & 73 & "I & " & $+\quad 51$ & & -53 \\
\hline \multirow[t]{2}{*}{$30, \quad 4,1973$} & 61 & Air Tight & - & +++17 & +13 & -69 \\
\hline & 61 & Air Loose & - & +++17 & +15 & -68 \\
\hline \multirow{2}{*}{$\begin{array}{rrr}18, & 6, & 1973 \\
5, & 7, & 1973\end{array}$} & 71 & Air Tight & Malachite Green (-) & +++17 & +35 & -33 \\
\hline & 68 & Air Tight & $\begin{array}{l}\text { Malachite Green }(-) \\
\text { Hemin } 5 \mu \mathrm{g} / \mathrm{ml}\end{array}$ & +++41 & & -5 \\
\hline \multirow{3}{*}{$\begin{array}{lll}18, & 7, & 1973 \\
23, & 7, & 1973\end{array}$} & 55 & Air Tight & Hemin $5 \mu \mathrm{g} / \mathrm{ml}$ & \multirow{3}{*}{$\begin{array}{l}+++35 \\
+++45 \\
+++24\end{array}$} & \multicolumn{2}{|l|}{+17} \\
\hline & 50 & Air Loose & Hemin $5 \mu \mathrm{g} / \mathrm{ml}$ & & & \\
\hline & 50 & "I & $\begin{array}{l}\text { Malachite Green (-) } \\
\text { Hemin } 5 \mu \mathrm{g} / \mathrm{ml}\end{array}$ & & & \\
\hline \multirow{2}{*}{$\begin{array}{lll}27, & 10, & 1973 \\
15, & 12, & 1973\end{array}$} & 72 & Air Loose & Malachite Green (-) & \multirow{2}{*}{$\begin{array}{l}+++88 \\
+++21\end{array}$} & +10 & -5 \\
\hline & 110 & Air Loose & $\begin{array}{l}\text { Malachite Green }(-) \\
\text { Hemin } 5 \mu \mathrm{g} / \mathrm{ml}\end{array}$ & & & -9 \\
\hline
\end{tabular}

Table 2 Passage Cultivation of M. lepraemurium on Modified $1 \%$ Ogawa Yolk Media

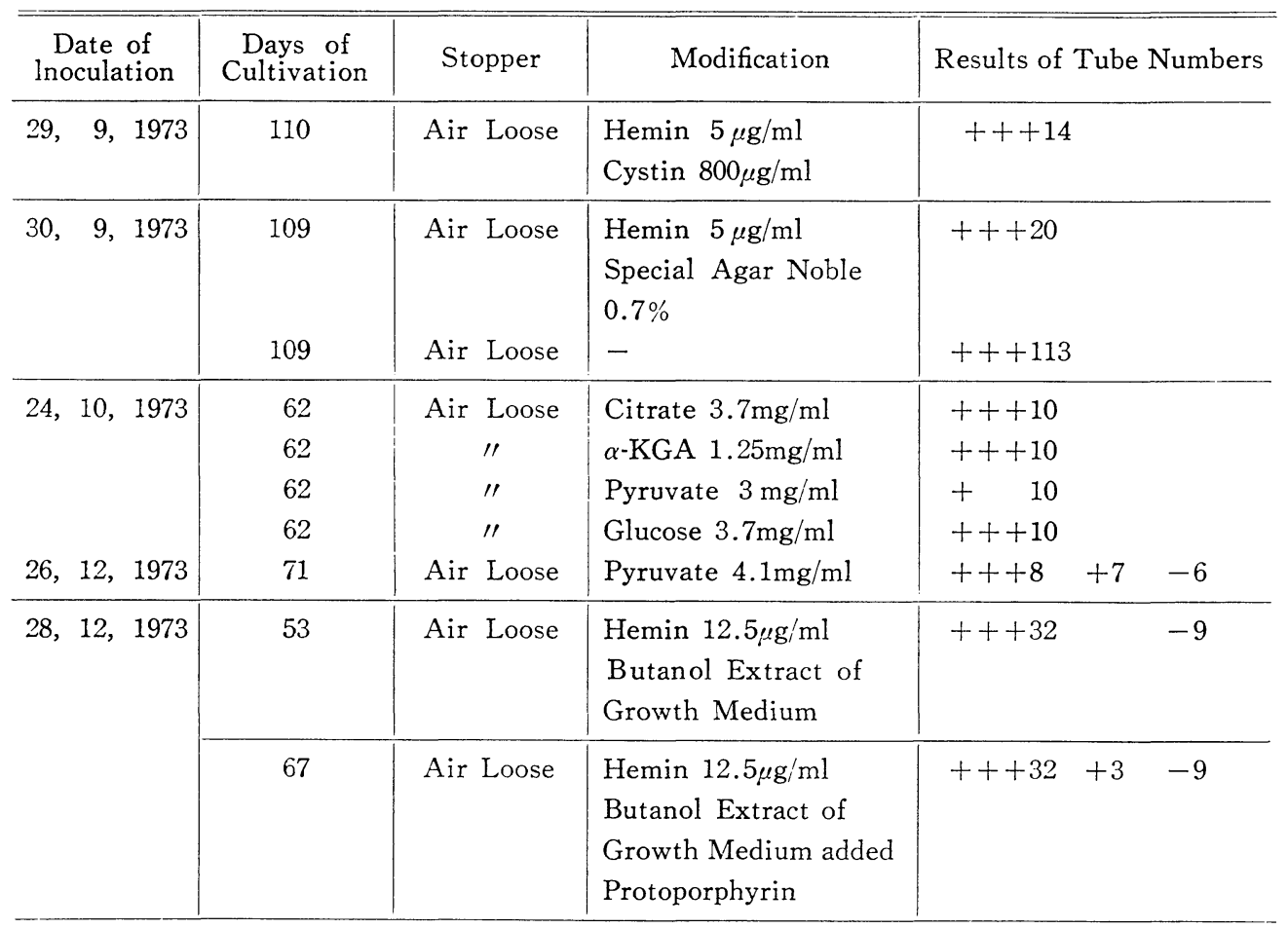


Table 3 Passage Cultivation of M. lepraemurium on Modified $1 \%$ Ogawa Yolk Media

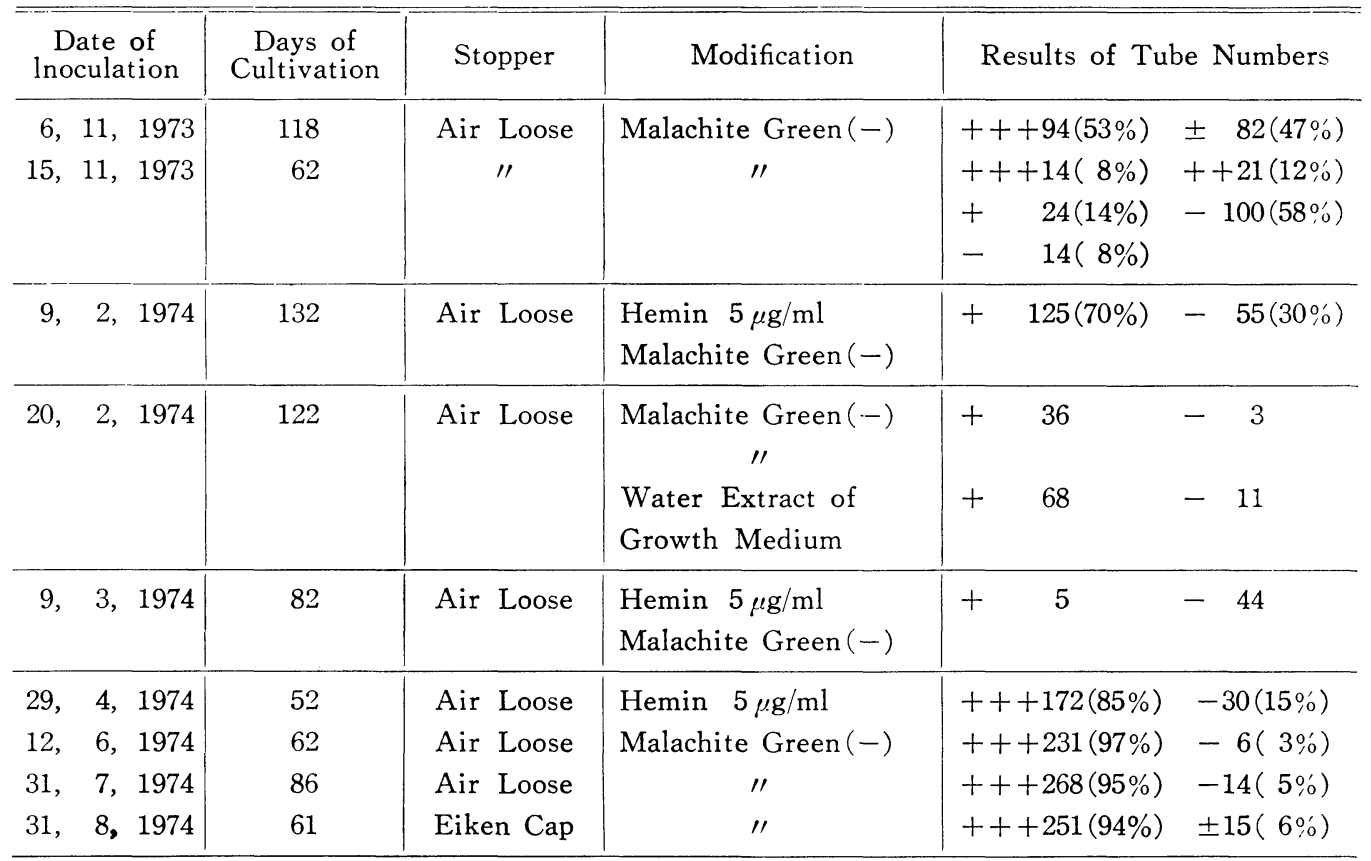

Table 4 Effect of Hemin and Protoporphyrin on the Growth of M. lepraemurium

\begin{tabular}{|c|c|c|c|c|c|c|c|c|c|}
\hline \multirow[b]{2}{*}{ Control } & \multicolumn{2}{|c|}{ after 45 days } & \multicolumn{2}{|c|}{85 days } & & \multicolumn{2}{|c|}{45 days } & \multicolumn{2}{|c|}{85 days } \\
\hline & $\begin{array}{l}+++ \\
++ \\
\pm\end{array}$ & $\begin{array}{r}9 \\
13 \\
17\end{array}$ & $\begin{array}{l}+++ \\
+ \\
-\end{array}$ & $\begin{array}{r}24 \\
4 \\
11\end{array}$ & & & & & \\
\hline $\begin{array}{l}\text { Hemin } \\
5 \mu \mathrm{g}\end{array}$ & $\begin{array}{l}+++ \\
++ \\
+\end{array}$ & $\begin{array}{r}10 \\
20 \\
7\end{array}$ & $\begin{array}{l}+++ \\
+ \\
-\end{array}$ & $\begin{array}{r}33 \\
1 \\
3\end{array}$ & $\begin{array}{l}\text { Protoporphyrin } \\
5 \mu \mathrm{g}\end{array}$ & $\begin{array}{l}+++ \\
+ \\
+ \\
-\end{array}$ & $\begin{array}{r}7 \\
8 \\
18 \\
4\end{array}$ & $\begin{array}{l}+++ \\
+ \\
-\end{array}$ & $\begin{array}{r}26 \\
3 \\
8\end{array}$ \\
\hline $10 \mu \mathrm{g}$ & $\begin{array}{l}+++ \\
++ \\
+ \\
-\end{array}$ & $\begin{array}{r}2 \\
16 \\
18 \\
1\end{array}$ & $\begin{array}{l}+++ \\
+ \\
- \\
x\end{array}$ & $\begin{array}{r}24 \\
4 \\
3 \\
7\end{array}$ & $10 \mu \mathrm{g}$ & $\begin{array}{l}+++ \\
++ \\
+ \\
-\end{array}$ & $\begin{array}{r}8 \\
13 \\
13 \\
5\end{array}$ & $\begin{array}{l}+++ \\
+ \\
- \\
\times\end{array}$ & $\begin{array}{r}21 \\
7 \\
8 \\
3\end{array}$ \\
\hline $20 \mu \mathrm{g}$ & $\begin{array}{l}+++ \\
++ \\
+ \\
-\end{array}$ & $\begin{array}{r}3 \\
27 \\
7 \\
1\end{array}$ & $\begin{array}{l}+++3 \\
+ \\
-\end{array}$ & $\begin{array}{r}31 \\
4 \\
3\end{array}$ & $20 \mu \mathrm{g}$ & $\begin{array}{l}+++ \\
++ \\
+ \\
-\end{array}$ & $\begin{array}{r}9 \\
11 \\
14 \\
3\end{array}$ & $\begin{array}{l}+++ \\
+ \\
-\end{array}$ & $\begin{array}{r}23 \\
5 \\
9\end{array}$ \\
\hline $50 \mu \mathrm{g}$ & $\begin{array}{l}+++ \\
++ \\
+ \\
-\end{array}$ & $\begin{array}{r}0 \\
0 \\
6 \\
29\end{array}$ & & & $50 \mu \mathrm{g}$ & $\begin{array}{l}++t \\
+ \\
+ \\
-\end{array}$ & $\begin{array}{r}10 \\
9 \\
14 \\
6\end{array}$ & $\begin{array}{l}+++ \\
+ \\
-\end{array}$ & $\begin{array}{r}22 \\
5 \\
12\end{array}$ \\
\hline
\end{tabular}


ら炭素源の添加効果を検討したが，Table 2 に示すよう に鼠䙡菌の増殖は添加物を加えない対照の培地に劣ると も優るものではなかった。中でも焦性ブドウ酸の添加に おいて増殖が悪かったので 2 回実験を行つたが，やはり 焦性ブドウ酸を添加すると鼠癩菌の增殖はよくなかっ た。

鼠癩菌の継代において大量接種すれば，接種菌が培地 にして増殖に好都合な条件を作るのではないかと考え て，鼠癩菌のよく増殖した $1 \%$ 小川卵黄培地（マラカイ トグリーン無添加）から水抽出物（Table 3) およびブ タノール抽出物（Table 2）を作り，夫々 $1 \%$ 小川卵黄 培地に添加してみたが，これによって著明に鼠瀬菌の増 殖がよくなることはなかった。

中村14) $\mathrm{NC}$ 培地にへミンを添加した NC 3 培地で は鼠癩菌の増殖がよくなると報告しているので，1\%小 川卵黄培地にへミンの添加効果を検討した。Table 1 に てはへミンを添加した方が鼠癩菌継代陽性率がよかった が，Table 3 の1974年 3 月 9 日に継代した実験にてはへ ミンの添加効果は全然なかった。ここで気づいたことは 継代に用うる菌が 2 ケ月を過ぎた古い培養の菌では死菌 が多く継代の陽性率が悪くなるということであった。そ こで継代の鼠癩菌を30日から40日間培養し，よく増殖し た Rough の菌を用いて，ヘミン添加の影響をみた。 Table 3 の最後の欄にみらるれるように， ヘミンの添 加, 無添加によって鼠瀬菌の継代にさしたる影響はない という結果がえられた。ヘミン無添加の培地で最も継代 率のよかったときは，237 本中 6 本が陰性で，陰性率は 僅か $3 \%$ という成績であった。ヘミンと同時にプロトポ ルフィリンの添加効果も検討したが, Table 4 に示した ようにプロトポルフィリン添加は対照の $1 \%$ 小川卵黄培 地の成績と大差なく，ヘミン添加では多少ながら対照培 地よりまさるようであった。しかしながらへミンはトリ メチルアミンにとかしているので， $50 \mu \mathrm{g} / \mathrm{ml}$ の量を添 加するとトリメチルアミンの影響が出るためかすべて陰 性の結果となっている。

Table 3 の1973年11月15日継代の欄にてー14（8\%） とー100 (58\%) と陰性の成績が二つに分けて記載して いるが, $-14(8 \%)$ というのは大量接種して1 ケ月後 菌塊の増殖がみられなかったもの，－100（58\%）とい うのは 1 ケ月目では増殖と判定したものの内，凝水とと もに培地全面に塗沫して抾げた結果 2 ケ月後には増殖し なかったということである。これは大量菌接種にて 1 ケ 月後に増殖と判定した群の中に增殖のたしかでなかった ものが含まれていることを示し，大量菌接種における増
殖の判定は慎重にすべきであると思う。

Table 2 において添加物の影響をみた実験においては 100 \%増殖をみたことが多いが，これは鼠瀬菌を多量に 収獲する目的ではなかったため, 継代に用うる鼠癩菌を 培地の中央に集簇して継代したためである。1\%小川卵 黄培地にて鼠癩菌を増菌させて多量に集める目的のため に培地一面に点々と菌塊を移植する場合は，全部の菌が 枯死することがあるので，継代にはなるべく密に移植す ることが必要である。

\section{考察}

鼠癩菌の継代において斜面培地の中央に菌塊を少量移 植するのでは air tight と air loose の条件の差は著 明に現われない。試験管内に初めに含まれていた酸素の 量が鼠瀬菌の增殖を支持する程に存在しているからで， 移植菌量が多くなり，また増菌が進み試験管内の酸素の 消費量が多くなるに従って air tight のゴム栓では酸素 不足の現象が起るために, 移植された鼠瀬菌の增殖が阻 害されて, 自己融解を起すのであろう。このように一見 smooth 型に変ったように思われるコロニーから菌塊を 移植すると継代率が悪くなる。既ち自己融解のために死 菌が多くなっているのであろう。

ダブルゴム栓に手術用の絹糸を通して通気させる方法 も，その通気穴がふさがることがあり，継代移植した鼠 癩菌の増殖率に影響を興えることを考えて，栄研のゴム 栓を用いた。このゴム栓は内側に側溝があり，それを通 じて確実に通気状態が保たれるものである。

$1 \%$ 小川卵黄培地に添加物を加えて鼠瀬菌の継代率 をよくせしめようと考えた初期の目的に多少とも貢献 した物質としてへミンをとりあげることができたが， ミンを添加せずとも， air loose の条件で 30 日ないし40 日培養のよく增殖した鼠癩菌の菌塊を斜面培地の中央に 集簇すれば，概ね $100 \%$ に継代を成功させることができ る。なおへミンを $5 \mu \mathrm{g} / \mathrm{ml}$ の割に添加す机ばこれを一層 確実にすることができる。

\section{総 括}

1. $1 \%$ 小川卵黄培地からマラカイトグリーンを除い ても鼠癩菌の継代培養に影響を与えなかった。

2. $1 \%$ 小川卵黄培地に次のような物質を添加しても 鼠瀬菌の継代培養に影響を与えなかった。シスチン，シ スティン, special agarnoble, クエン酸ソーダ, $\alpha$-ケト グルタール酸ソーダ，ブドウ糖，プロトポルフィリン， 鼠癩菌の増殖した培地の水抽出画分およびブタノール抽 
出画分。

3. $1 \%$ 小川卵黄培地に焦性ブドウ酸を添加すると鼠 癩菌の継代培養に悪影響を与えた。

4. $1 \%$ 小川畉黄培地にへミンを添加すると鼠瀬菌の 継代培養によりよい結果がられた。

5. ゴム栓に細穴をあけた air loose の条件が air tight の条件よりも鼠癩菌の継代培養によい結果を与え た。

6. 鼠瀬菌の継代に用うる菌は 2 ケ月以上経たものは さけるべきで，30日ないし40日間培養の増殖のよい Rough の菌を用うるのがよい。さらに継代の陽性率を あげるためには培地一面に分散して播種するのではな く，培地の中央に集簇して播種するのがよい。

\section{謝辞}

本研究にあたり培地作成の学 いた斉藤和子さんに深謝するとともに，研究費の一部は 日米医学協力計画らい専門部会および World Health

Organisation の援助によった。ここに謝意を婊す。

\section{文献}

1）小川辰次, 本村恵子：鼠らい菌に関する研究, 第 1 報, 鼠らい菌培養の試み, レプラ， 38 : 246-254 (1969).

2) 小川辰次, 本村恵子：鼠らい菌に関する研究, 第 2 報, 我々の分離した菌の性状に関するその 後の成績と $1 \%$ 畉黄培地の吟味, レプラ, 40 : 8-15 (1971).

3) 内田三千太郎, 小川辰次：鼠らい菌培盖の小英 験, レプラ, $40: 57-61$ (1971).

4) 小川辰次, 本村恵子：鼠らい菌に関する研究, 第 3 報, 初代培羡に打ける前処理の雑菌侵入お よびハワイ株様抗酸菌の発去に及ぼす影響，レ プラ, $40:$ 149-155 (1971).

5) 小川辰次, 本村恵子：鼠らい菌に関する研究, 第 4 報，鼠らい菌（ハワイ）株培養の㪶み一分離
培差，継代培瀁，復元試験の続報，レプラ，40： 199-207 (1971).

6) 小川辰次，平木美奈子：鼠らい菌に関する研究， 第 5 報， $1 \%$ 沺黄培地に混入されている $\mathrm{KH}_{2}$ $\mathrm{PO}_{4}$, グルタミン酸ナトリウム,グリセリンの量 および培地 $\mathrm{pH}$ の検討，レプラ，41:113-117 (1972).

7）小川辰次，平木美奈于：鼠らい菌に関する研究， 第 6 報，鼠らい菌の分離培養の試み一けいしち 上う株接種マウスよりの分離培養, レプラ, 41 : 118-123 (1972).

8）小川辰次，平木美奈子：鼠らい菌に関する研究, 第 7 報, 鼠ら以菌梂抗酸菌の発育温度域と発姢 至適温度，レプラ，41：176-181（1972）。

9）小川辰次，平木美奈子：鼠らい菌に関する研究， 第 8 報，6代継代のハワイ株様抗酸菌の種々の 菌量の感染によるマウスへの復元試験，レプラ， 42 : 218-227 (1973).

10）小関勇一，安地節，岡本茂広：鼠瀨菌感染マウ スより分離された小川氏抗酸菌について，第 1 報, 試験管内培養と動物接種, レプラ， 41 : 127-136 (1972).

11）小関勇一, 岡本茂厸, 安地節: 鼠癩菌感染マウ スより分離された小川氏抗酸菌について，第 2 報, 薬剂感受性と 2,3 の鑑別試験, レプラ, 41 : 137-148 (1972).

12）森 竜男：小川卵黄培地による鼠桷菌培羡と増 殖菌の動物接種, レプラ, $43: 226-233$ (1974).

13) Nakamura, M.: Multiplication of Mycobacterium lepraemurium in cell-free liquid medium Proc. Japan. Acad., 49 : 42-46 (1973).

14）中村昌弘：無細胞液体培地に打ける鼠癩菌の増 菌，第 4 報, NC-3 培地の開発，レプラ，42： 161-164 (1973).

15）中村昌弘：無細胞液体培地に打ける鼠癩菌の堌 殖，第 5 報， NC-5 培地の開発，レプラ，42： 205-209 (1973).

16）小関勇一, 安地節: 小川菌の発充と小川培地の $\mathrm{pH}$, 小川菌の発青と通気, レプラ, $42: 89$ (1973). 